\title{
Human leukocyte antigen HLADRB1 determinants susceptibility to gastroesophageal reflux disease
}

\author{
Batool Mutar MAHDI ${ }^{1}$, Riyadh Mohamad HASAN² and Wafaa Hazim SALIH ${ }^{1}$
}

Received 25/8/2016

Accepted 20/9/2016

\begin{abstract}
Background - Gastroesophageal reflux disease (GERD) is characterized by diverse symptoms. There is an evidence for a genetic component to GERD as supported by familial aggregation of this disease. Objective - To investigate whether certain human leucocyte antigen genes HLA-DRB1 are associated with GERD. Methods - Patients and controls were prospectively recruited from GIT center at Al-Kindy Teaching Hospital (Baghdad-Iraq) between January 2014 and July 2016. Sixty Iraqi Arab Muslims patients with a history of heartburn and dyspepsia compared with 100 Iraqi Arab Muslims controls. All study patients and control groups underwent upper gastrointestinal endoscopic examinations and their serums were analyzed for CagA antibodies Immunoglobulin G (IgG) for H. pylori. HLA-DRB1 genotyping were done to both groups. Results - A total of 60 patients with erosive gastritis; GERD (Grade II and III) were evaluated, together with 100 controls. There is a significant increase of $H$. pylori infection $(P=0.0001)$ in GERD patients than control group. HLA-DRB1* 15:01 was significantly increased in GERD patients in comparison with control group and an increased frequency of HLADRB1*11:01 in control group compared with patients group. Conclusion - There is an association between HLA-DRB1

*15:01 in GERD patients with H. pylori positive patients.
\end{abstract}

HEADINGS - HLA-DR1 antigen. Gastroesophageal reflux. Helicobacter pylori.

\section{INTRODUCTION}

Gastroesophageal reflux disease (GERD) is the end results of involuntary gastric contents reflux into the esophagus, causing heartburn and acid regurgitation symptoms or injury to esophageal tissue ${ }^{(2,13)}$. Thus, esophagitis is considered as a complication of GERD ${ }^{(25)}$. GERD includes two types; erosive esophagitis and non-erosive reflux disease (NERD) (endoscopy-negative reflux disease $)^{(1)}$. GERD classified into four grades (A, B, C and D) according to Los Angeles classification ${ }^{(22)}$. Other classification was Savary - Miller that classified it into five grades (I, II, III, IV and $\mathrm{V}{ }^{(4)}$. The prevalence of GERD symptoms varies between $9 \%$ and $42 \%$. ${ }^{(15)}$. In spite of high prevalence of GERD symptoms, its aetiology is still not completely understood ${ }^{(9)}$. One of the important factors in the causation of GERD is environmental factors ${ }^{(3)}$. These include life style factors like body weight, nutrition, alcohol consumption, smoking, the intake of non-steroidal anti-inflammatory drugs, and sleeping position ${ }^{(16)}$. Regarding genetic factors; there is an evidence for the role of genetic component to GERD as confirmed by familial aggregation of GERD symptoms ${ }^{(21)}$. Other studies done in Sweden and UK in monozygotic and dizygotic twins revealed considerable genetic contribution to the aetiology of GERD ${ }^{(3,6)}$. Prevalence of gastrointestinal reflux symptoms in Asian population are affected by racial and ethnic factors ${ }^{(8,14)}$. All these suggest a genetic etiology of GERD in addition to environmental factors. Other genetic factor is Human Leukocyte Antigen (HLA) system, which has an extensive polymorphism and considered as an excellent marker for population genetic analyses and disease association. Rajendra et al. ${ }^{(18)}$ found that inheritance of the HLA-B*07 gene confers an increased risk for
Barrett's esophagus in south Asians (mostly south Indians) but not Orientals (Malays and Chinese). They also showed that HLA-B*07 positive patients with Barrett's esophagus had a significantly higher family history of GERD symptoms, compared with their HLA-B*07 negative counterparts. HLA molecules perform a central function in the regulation of the immune response in many diseases. HLA alleles might predispose some individuals to particular diseases and malignancies ${ }^{(11)}$. Many studies found the associations between HLA alleles and susceptibility or resistance to certain diseases.

In this study, we examine if the human leucocyte antigen HLADRB1 alleles, important for immune responsiveness, may be a susceptibility locus for GERD disease in Iraqi Arab Muslims patients.

\section{METHODS}

Patients and controls were prospectively recruited from GIT center at Al-Kindy Teaching Hospital (Baghdad-Iraq) between January 2014 and July 2016. The demographic details of all patients and control groups were recorded. Written informed consent was obtained from all patients and control group for this study. The study protocol was reviewed and approved by the Scientific and Ethical Committee of Al-kindy medical college and Al-Kindy Teaching Hospital. The patient group and control groups were sex and age matched.

Sixty Iraqi Arab Muslims patients with a history of heartburn and dyspepsia at least three times a week for a period of more than 3 months and had been referred for upper gastrointestinal endoscopy at GIT center at Al-Kindy Teaching Hospital, Baghdad and a diagnosis of GERD were prospectively recruited. 
Exclusion criteria included those patients with Barrett's esophagus and esophageal varices. Patients with secondary causes of gastro-oesophageal reflux disease, patients who had consumed antacids, $\mathrm{H} 2$ blockers, proton pump inhibitors (PPIs), non-steroidal anti-inflammatory drugs (NSAIDs), alcohol, history of Helicobacter pylori eradication, subjects with a history of gastrointestinal surgery, peptic ulcer, and gastric cancer or with systemic disease requiring chronic medication were excluded.

The 100 Iraqi Arab Muslims controls consisted of people undergoing upper gastrointestinal endoscopy for reasons other than reflux symptoms, Barrett's esophagus or any form of dyspepsia and heartburn. This group included those with normal OGD and being investigated for anaemia or faecal occult blood positive stools, chronic diarrhoea for unknown reason requiring small bowel biopsy, irritable bowel syndrome and screening for familial adenomatous polyposis.

\section{Oesophagogastric examinations}

All studied patients and control groups underwent upper gastrointestinal endoscopic examinations using gastroscope: GIF-H260; Olympus, Tokyo, Japan and Display screen; Olympus OEV-261H liquid crystal display monitor; Olympus, Tokyo, Japan. The gastroesophageal junction was defined as the squamocolumnar junction and the proximal margin of gastric folds. The endoscopic findings of erosive esophagitis in the lower esophagus were classified using the Savary and Miller classification. All of them either Grade II which is confluent erosive or exudative mucosal lesions which do not extend around the entire esophageal circumference or Grade III which is erosive or exudative mucosal lesions which cover the entire esophageal circumference and lead to inflammation of the wall without stricture (according to Savary and Miller, 1979) ${ }^{(23)}$. Histopathological study was done by taking specimens from gastric mucosa to confirm the diagnosis and presence of $H$. pylori.

\section{Serological tests}

Blood samples $(3 \mathrm{~mL})$ were drawn into plain tube. Separated serums were analyzed for CagA antibodies Immunoglobulin $\mathrm{G}$ (IgG) for H. pylori using an immunological test (immunochromatography test) (ACON, USA).

\section{HLA Class II genotyping (HLA-DRB1)}

Two $\mathrm{mL}$ of venous blood were collected in EDTA containers for DNA extraction from human blood using blood kit (QIAmp DNA blood Mini Kit, QIAGEN INC- Germany).

DNA concentration and purification product was estimated using Nanodrop -South Korea. DNA was verified by electrophoresis in a $2 \%$ agarose gel containing ethidium bromide and was visualized under UV light.

Locus- and allele-specific amplification of genomic patients and control DNA was performed for DRB1. DNA Amplification and Hybridization was performed using a sequence-specific oligonucleotide probes (SSOP) by HLA-DRB1 amplification and hybridization kits (SSO HLA type DRB1 plus and Mastermix for HLA type DRB1 Amp plus kits -Innogenetics-Belgium) by AutoLipa - 48Innogenetics-Belgum. The results were interpreted using LiRas version-5.0 software- Innogenetics-Belgium.

\section{Statistical analysis}

HLA-DRB1 frequencies were determined by direct counting. The frequency of each allele was compared between patients and control group using chi-square test Fisher exact test using MiniTab version. 3.0 software. In each comparison, the Odds ratio (OR) along with the $95 \%$ confidence interval $(95 \% \mathrm{CI})$ was used. Gene frequencies for both groups were calculated. $P$-value less than 0.05 were considered statistically significant.

\section{RESULTS}

A total of 60 patients with erosive gastritis; GERD (Grade II and III) were evaluated, together with 100 controls. The mean age of patients was $45.67 \pm 5.54$, as compared with $44 \pm 15.22$ for the controls. The male to female sex ratio was 1.0 in the patients group versus also 1.0 in controls. About 50\% of them were GERD II and the rest were GERD III by endoscopy.

There is a significant increase of $H$. pylori infection $(P=0.0001)$ in GERD patients than control group. The Odd ratio $(\mathrm{OD})=18.00$ with $95 \% \mathrm{CI}=$ from $7.727-41.926$. The relative risk $=6.666$ that indicates an association between $H$. pylori and disease as shown in Table 1. Control and patients were typed for identifying the DRB1* alleles using DNA based methodology (PCR-SSOP). There was an increased frequency of HLADRB1*11:01 in control group compared with patients group $(P=0.0001$, Odds ratio $=0.141$, 95\% CI: 0.055-0.358). Other allele like HLA-DRB1* 15:01 was significantly increased in GERD patients in comparison with control group $(P=0.004$, Odds ratio $=3.833,95 \%$ CI: $1.513-9.708)$ as shown in Table 2.

The highest genotype frequency in GERD patients was 15:01 which is equal to 0.065 while in the control group was 11:01 which is 0.117 as shown in Table 3 .

The distribution of HLA polymorphism HLA*DRB1 was investigated in the control and patients groups of Iraqi Arab Muslims. The observed and expected phenotypes of all loci for the patients group as demonstrated in Table 4 were in a good agreement with Hardy-Weinberg equilibrium as shown in Table 5.

TABLE 1. Helicobacter pylori in GERD (Grade II and III) patients compared with control group

\begin{tabular}{lccccc}
\hline $\begin{array}{l}\text { H. pylori } \\
\text { Cag A+ } \\
\text { Status }\end{array}$ & $\begin{array}{c}\text { GERD+ } \\
\text { patients } \\
\text { N }(\%)\end{array}$ & $\begin{array}{c}\text { GERD - } \\
\text { Control } \\
\text { N }(\%)\end{array}$ & P-value & $\begin{array}{c}\text { Odd ratio } \\
95 \% \text { CI }\end{array}$ & $\begin{array}{c}\text { RR } \\
\text { Relative } \\
\text { risk }\end{array}$ \\
\hline $\begin{array}{l}\text { H. pylori } \\
\text { Positive }\end{array}$ & 40 & $10(10)$ & 0.0001 & 18.00 & 6.666 \\
& $(66.66)$ & & & $7.727-$ & \\
H. pylori & 20 & $90(90)$ & & & \\
Negative & $(33.33)$ & & & \\
& & & & & \\
Total & 60 & 100 & & & \\
\end{tabular}

GERD: gastroesophageal reflux disease 
TABLE 2. Frequencies of HLA-DRB1 alleles in patients with GERD disease compared with control group

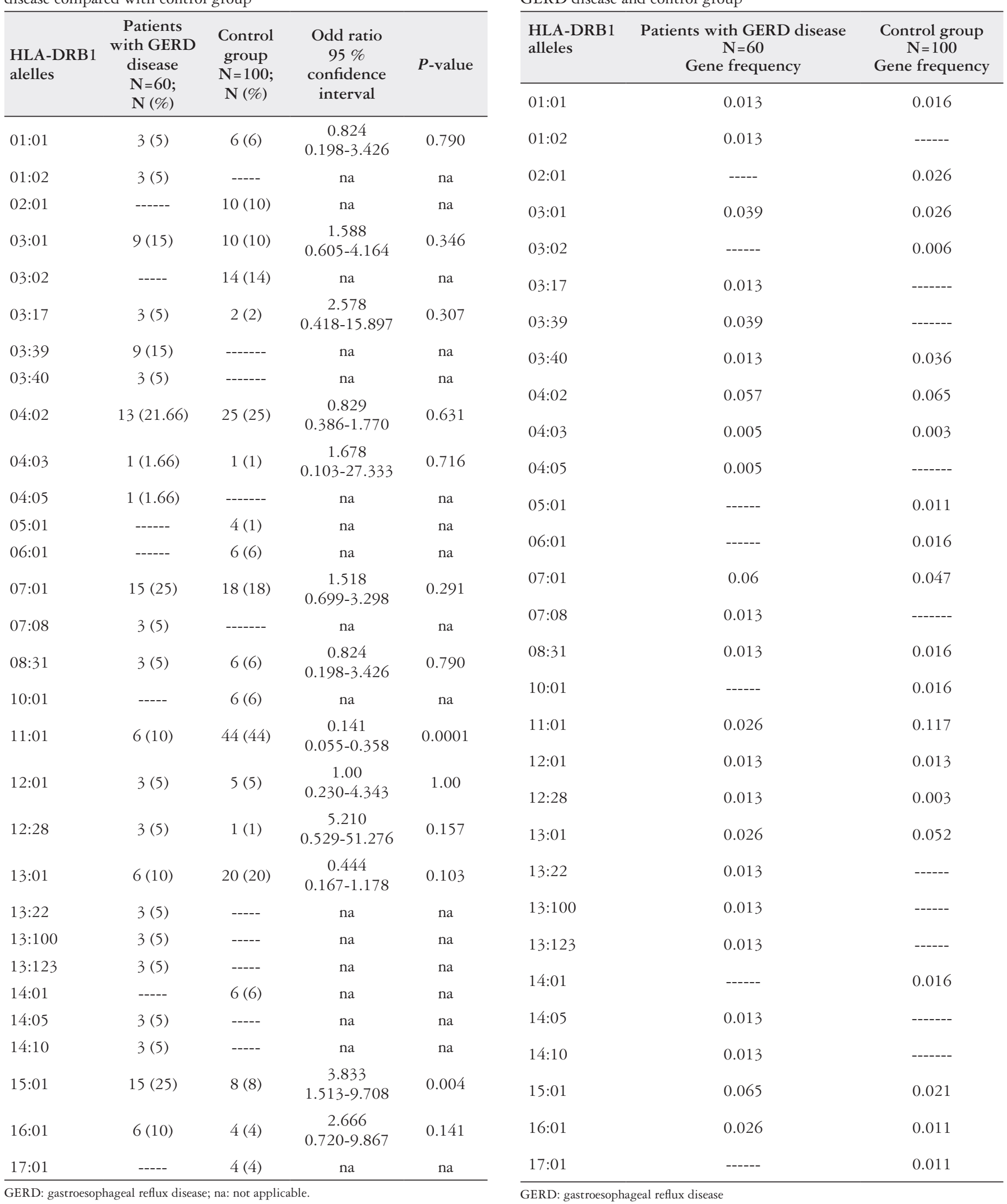

TABLE 3. Genotypes frequencies of HLA-DRB1 alleles in patients with GERD disease and control group

GERD: gastroesophageal reflux disease 
TABLE 4. Observed and expected numbers and percentages of HLA-DRB1 alleles in patients with GERD disease

\begin{tabular}{|c|c|c|}
\hline $\begin{array}{l}\text { HLA-DRB } 1 \\
\text { alelles }\end{array}$ & $\begin{array}{c}\text { Patients with GERD } \\
\text { disease } \\
\text { Observed }(\mathbf{N}=60) \\
\text { N }(\%)\end{array}$ & $\begin{array}{l}\text { Patients with GERD } \\
\text { disease } \\
\text { Expected }(\mathrm{N}=60) \\
\mathrm{N}(\%)\end{array}$ \\
\hline 01:01 & $3(5)$ & $3.09(5.15)$ \\
\hline 01:02 & $3(5)$ & $3.09(5.15)$ \\
\hline 02:01 & ------ & ------ \\
\hline 03:01 & $9(15)$ & $9.17(15.28)$ \\
\hline 03:02 & ----- & ----- \\
\hline $03: 17$ & $3(5)$ & $3.09(5.15)$ \\
\hline $03: 39$ & $9(15)$ & $9.17(15.28)$ \\
\hline $03: 40$ & $3(5)$ & $3.09(5.15)$ \\
\hline 04:02 & $13(21.66)$ & $13.28(22.13)$ \\
\hline 04:03 & $1(1.66)$ & 1.19 (1.98) \\
\hline 04:05 & $1(1.66)$ & $1.19(1.98)$ \\
\hline 05:01 & ------ & ------ \\
\hline 06:01 & ------ & ------ \\
\hline 07:01 & $15(25)$ & $15.09(25.15)$ \\
\hline 07:08 & $3(5)$ & $3.09(5.15)$ \\
\hline $08: 31$ & $3(5)$ & $3.09(5.15)$ \\
\hline 10:01 & ----- & ------- \\
\hline 11:01 & $6(10)$ & $6.07(10.11)$ \\
\hline $12: 01$ & $3(5)$ & $3.09(5.15)$ \\
\hline $12: 28$ & $3(5)$ & $3.09(5.15)$ \\
\hline $13: 01$ & $6(10)$ & $6.07(10.11)$ \\
\hline $13: 22$ & $3(5)$ & $3.09(5.15)$ \\
\hline $13: 100$ & $3(5)$ & $3.09(5.15)$ \\
\hline $13: 123$ & $3(5)$ & $3.09(5.15)$ \\
\hline 14:01 & ----- & ------- \\
\hline $14: 05$ & $3(5)$ & $3.09(5.15)$ \\
\hline $14: 10$ & $3(5)$ & $3.09(5.15)$ \\
\hline $15: 01$ & $15(25)$ & $15.09(25.15)$ \\
\hline $16: 01$ & $6(10)$ & $6.07(10.11)$ \\
\hline $17: 01$ & ----- & ------ \\
\hline
\end{tabular}

GERD: gastroesophageal reflux disease

TABLE 5. Hardy - Weinberg equilibrium in HLA-DRB1 locus of patients with GERD disease

\begin{tabular}{lccc}
\hline HLA locus & Chi $^{2}$ & DF & $P$ \\
\hline DRB1 & 0.106 & 22 & Not significant \\
\hline
\end{tabular}

GERD: gastroesophageal reflux disease

\section{DISCUSSION}

Erosive type of Gastroesophageal reflux disease (GERD) predisposes to Grade IV Barrett's esophagus that leads to esophageal adenocarcinoma $^{(7)}$. Any abnormal cell express new antigens as a result of the multiple genetic changes that are associated with cell inflammation or transformation ${ }^{(11)}$, that recognized by $\mathrm{T}$ helper or $\mathrm{T}$ cytotoxic cells presented by human leucocyte antigen (HLA) class I or class II molecules ${ }^{(24)}$. HLA system is highly polymorphism system and excellent marker for population genetic analyses and disease association studies. HLA molecules perform a crucial and important function in the regulation of the immune response In this study, HLA-DRB1* 15:01 was significantly increased in GERD patients in comparison with control group $(P=0.004$, Odds ratio $=3.833,95 \%$ CI: 1.513-9.708). Thus, this allele considered as predisposing factor for GERD while HLADRB1*11:01 is a protective factor because there is an increased frequency of HLADRB1*11:01 in control group compared with patients group $(P=0.0001$, Odds ratio $=0.141,95 \% \mathrm{CI}$ : $0.055-0.358$ ). The expression of HLA-DR antigens is more complex. The squamous epithelium of the esophagus is devoid of HLA class II expression, like lung, stomach and breast epithelium ${ }^{(5,17)}$. The increased expression of class II may be due to infection with $\mathrm{H}$. pylori that constitutes $66.66 \%$ of GERD patients and there is a significant increase of $H$. pylori infection $(P=0.0001)$ in GERD patients than control group. HLA class II antigens appear in pathological circumstances, like in inflammation, infection, tumour transformation and autoimmunity ${ }^{(20)}$. Other study demonstrated the association between Barrett's esophagus in Asians, particularly Indians, with HLA-B7; reinforcing a genetic component to gastroesophageal reflux disease ${ }^{(18)}$. The prevalence of GERD is differed in different ethnic countries across the world, there is a higher prevalence rates in Western countries compared with the Far East. Among oriental countries, GERD may be more common in Japan compared with Hong Kong, Singapore and Korea. Studies suggest that GERD is relatively frequent in the Middle East, although a comparison of Turkish and ethnically Dutch patients in Holland showed a lower prevalence of reflux esophagitis in Turkish individuals compared with the ethnically Dutch ${ }^{(1)}$. Ethnic differences in the prevalence of GERD with familial aggregation suggest the possibility of a genetic component to GERD in addition to environmental factors, e.g. Helicobacter pylori infection, abdominal adiposity and metabolic syndrome. The HLA-B07 gene commonly found in South Asian and Caucasian populations, but not Orientals, and the high prevalence of H. pylori in South Asians and the consequent atrophic gastritis and hypochlorhydria may partially ameliorate this genetic predisposition to disease ${ }^{(19)}$. Other study found increase frequency of GERD with gastrointestinal malformation in children that supporting a genetic part to gastro-oesophageal reflux disease ${ }^{(12)}$. A larger sample size and different ethnic populations Other than Arab populations should be genotyped to further confirm this association and identify possible additional risk factors in the human leucocyte antigen locus.

\section{CONCLUSION}

There is an association between HLA-DRB1 * 15:01 in GERD patients with $H$. pylori positive patients.

\section{Authors' contributions}

Mahdi BM: design the research, did the tests, write the manuscript, analysis data. Hasan RM did the gastroendoscopy to the patients and revise the manuscript. Salih WH did the tests and collect data and results. 
Mahdi BM, Hasan RM, Salih WH. Antígeno leucocitário humano HLADRB1 é determinante de susceptibilidade para a doença do refluxo. Arq Gastroenterol. 2017,54(1):41-5.

RESUMO - Contexto - A doença do refluxo gastroesofágico (DRGE) caracteriza-se por diversos sintomas. Há evidências de um componente genético para a doença de refluxo suportado pela agregação familiar desta doença. Objetivo - Investigar se certos genes de antígeno de leucócito humano HLADRB1 são associados à DRGE. Métodos - Pacientes e indivíduos controles foram recrutados prospectivamente do centro GIT no Al-Kindy Hospital (Bagdá-Iraque) entre de 2014 janeiro e julho de 2016. Sessenta pacientes muçulmanos árabes iraquianos com uma história de azia e dispepsia foram comparados com 100 indivíduos controles. Todos os pacientes do estudo e grupos de controle foram submetidos a exames de endoscopia gastrointestinal alta e seus soros foram analisados para anticorpos CagA imunoglobulina G (IgG) para H. pylori. Genotipagem HLA-DRB1 foram feitas para ambos os grupos. Resultados - Um total de 60 pacientes com gastrite erosiva; GERD (grau II e III) foram avaliados, em conjunto com 100 controles. Houve aumento significativo de infecção pelo $H$. pylori $(P=0,0001)$ em pacientes com DRGE em relação ao grupo controle. O HLA-DRB1* 15:01 aumentou significativamente em pacientes com DRGE em comparação com o grupo controle e houve uma maior frequência de HLADRB1* 11:01 no grupo controle em comparação com o grupo de pacientes com DRGE. Conclusão - Há uma associação entre HLA-DRB1* 15:01 em pacientes com DRGE positivos para a infecção por H. pylori.

DESCRITORES - Antígeno HLA-DR1. Refluxo gastroesofágico. Helicobacter pylori.

\section{REFERENCES}

1. Barlow WJ, Orlando RC. The pathogenesis of heartburn in nonerosive reflux disease: a unifying hypothesis. Gastroenterology. 2005;128:771-8.

2. Bredenoord AJ, Weusten BL, Curvers WL, Timmer R, Smout AJ. Determinants of perception of heartburn and regurgitation. Gut. 2006;55:313-8.

3. Cameron AJ, Lagergren J, Henriksson C, Nyren O, Locke GR 3rd, Pedersen NL. Gastroesophageal reflux disease in monozygotic and dizygotic twins. Gastroenterology. 2001;122: 55-9.

4. Dent J. Endoscopic grading of reflux esophagitis: The past, present and future. Best Pract Res Clin Gastroenterology. 2008;22:585-99.

5. Garrido F, Cabrera T, Concha A, Glew S, Ruiz-Cabello F, Stern PL. Natura history of HLA expression during tumour development. Immunol Today. 1993; 14:491-9.

6. Gold BD. Review article: epidemiology and management of gastro-esophageal reflux in children. Aliment Pharmacol Ther. 2004;19(Suppl.1.):22-7.

7. Hameeteman W, Tytgat GNJ, Houthoff HJ, van den Tweel JG. Barrett's esophagus: development of dysplasia and adenocarcinoma. Gastroenterology. 1989;96:1249-56

8. Ho KY, Kang JY, Seow A. Prevalence of gastrointestinal symptoms in a multiracial Asian population, with particular reference to reflux-type symptoms. Am J Gastroenterol. 1998;93:1816-22.

9. Kahrilas PJ. GERD pathogenesis, pathophysiology, and clinical manifestations. Cleve Clin J Med. 2003; 70(Suppl. 5):S4-19.

10. Kang JY. Systematic review: geographical and ethnic differences in gastro-oesophageal reflux disease. Aliment Pharmacol Ther. 2004;20:705-17.

11. Little AM, Stern PL. Does HLA type predispose some individuals to cancer? Mol Med Today 1999;5:337-42.

12. Marseglia L, Manti S, D'Angelo G, Gitto E, Salpietro C, Centorrino A, Scalfari G, Santoro G, Impellizzeri P, Romeo C. Gastroesophageal reflux and congenital gastrointestinal malformations. World J Gastroenterol. 2015;28:8508-15.

13. Moss SF, Armstrong D, Arnold R, et al. GERD 2003 - a consensus on the way ahead. Digestion. 2003;67:111-7.
14. Neumann CS, Cooper BT. Ethnic differences in gastrooesophageal reflux disease. Eur J Gastroenterol Hepatol. 1999;11:735-9.

15. Nilsson M, Johnsen R, Ye W, Hveem K, Lagergren J. Prevalence of gastro-oesophageal reflux symptoms and the influence of age and sex. Scand J. Gastroenterol. $2004 ; 39: 1040-5$

16. Nocon M, Labenz J, Willich SN. Lifestyle factors and symptoms of gastro-oesophageal reflux - a population-based study. Aliment Pharmacol Ther. 2006;23, 169-74.

17. Rajendra S, Ackroyd R, Karim N, Mohan C, Ho JJ, Kutty MK. Loss of human leucocyte antigen class I and gain of class II expression are early events in carcinogenesis: clues from a study of Barrett's oesophagus. J Clin Pathol. 2006;59:952-7.

18. Rajendra S, Ackroyd R, Murad S, Mohan C, Ho JJ, Goh KL, Azrena A, Too CL. Human leucocyte antigen determinants of susceptibility to Barrett's oesophagus in Asians - a preliminary study. Aliment Pharmacol Ther. 2005;21:1377-83.

19. Rajendra S. Barrett's oesophagus in Asians-are ethnic differences due to genes or the environment? J Intern Med. 2011;270:421-7.

20. Rockett JC, Darnton SJ, Crocker J, Matthews HR, and A G Morris AG. Expression of HLA-ABC, HLA-DR and intercellular adhesion molecule-1 in oesophageal carcinoma. J Clin Pathol. 1995;48:539-44.

21. Romero Y, Cameron AJ, Locke GR, Schaid DJ, Slezak JM, Branch CD, Melton LJ. Familial aggregation of gastroesophageal reflux in patients with Barrett's esophagus and esophageal adenocarcinoma. Gastroenterology.1997; 113:1449-56.

22. Sami SS and Ragunath K. The Los Angeles classification of Gastroesopgageal reflux disease. Video journal and Encyclopedia of GI Endoscopy. 2013;1:103-4.

23. Savary M, Miller G. The Esophagus. Handbook and Atlas of Endoscopy. Solothurn: Gassmann Verlag, AG, 1978.

24. Townsend A, Ohlen C, Bastin J, Ljunggren HG, Foster L, Karre K. Association of class I major histocompatibility heavy and light chains induced by viral peptides. Nature. 1989;340:443-8.

25. Wong BC, Kinoshita Y. Systemic review on epidemiology of gastroesophageal reflux disease in Asia. Clin Gastroenterol Hepatol. 2006;4:398-407. 